\title{
PENCIPTAAN TEATER MERETAS ADAB BERANGKAT DARI TRADISI MELANGUN SUKU ANAK DALAM
}

\author{
Suci Lantika ${ }^{1 *}$, Sulaiman Juned ${ }^{2 *}$, Sahrul Nazar $^{3 *}$ \\ Program Studi Penciptaan Seni Teater Program Pascasarjana \\ Institut Seni Indonesia Padangpanjang \\ Jl. Bahder Johan, Guguak Malintang, Padangpanjang, Kota Padangpanjang, Kode Pos 27126 \\ Sumatera Barat. Indonesia \\ Email: sucilantika8@gmail.com, sulaimanjuned@gmail.com,sharief.kirun@gmail.com
}

\begin{abstract}
Abstrak
Karya Meretas Adab merupakan capaian dari proses penciptaan teater yang berlandaskan pada riset atas tradisi melangun suku Anak Dalam. Pendekatan bentuk yang dipilih dalam proses penciptaan ini adalah bentuk teater kontemporer. Rumusan masalah yang dipertanyakan dari penciptaan ini adalah bagaimana mewujudkan penciptaan teater kontemporer Meretas Adab berangkat dari tradisi Melangun. Teori yang digunakan adalah teori teater kontemporer, konvensi panggung proscenium dan eksplorasi seni budaya. Metode penyutradaraan yang digunakan terdiri dari, riset, penyusunan naskah, memilih tim kreatif, latihan terpisah dan latihan gabungan. Hasil dari proses penciptaan ini adalah pertunjukan teater yang memanfaatkan properti dan prilaku keseharian dari masyarakat suku Anak Dalam. Teater kontemporer ini memanfaatkan seni Melayu Jambi sebagai basis dari penciptaan komposisi musik dan tari.
\end{abstract}

Kata Kunci: meretas adab, melangun.

\begin{abstract}
The work of Meretas Adab is an achievement of the process of creating a theater based on research on the tradition of Melangun from Anak Dalam tribe. The form approach chosen in this creation process is a contemporary theatrical form. The formulation of the problem in question from this creation is how to realize the creation of a contemporary theater of Meretas Adab departing from the Melangun tradition. The theories used are contemporary theater theory, proscenium stage conventions and cultural arts exploration. The directing method used consisted of research, script preparation, selecting a creative team, separate exercises and joint exercises. The result of this creation process is a theatrical performance that utilizes the properties and daily behavior of the Anak Dalam tribal community. This contemporary theater utilizes Jambi Malay art as the basis for creating musical and dance compositions.
\end{abstract}

Keywords: meretas adab, melangun.

\section{PENDAHULUAN}

Suku Anak Dalam adalah masyarakat yang tinggal di pedalaman hutan Sumatera. Kelompok konservatif yang jauh dari sentuhan kehidupan modern ini masih menggantungkan hidup dari alam. Suku bangsa yang juga dikenal dengan sebutan Orang Rimba ini memiliki populasi mayoritas di hutan Jambi. Ibrahim (2013: 03) menyebutkan: "Suku Anak Dalam tergolong sebagai rumpun pra-Melayu yang merupakan penduduk asli dari pulau Sumatera". Nama lain dari suku Anak Dalam adalah Komunitas Adat Terpencil, Orang kubu dan Orang Rimba (Mailinar, 2013: 143).

"Populasi Suku Anak Dalam berjumlah 3.198 jiwa yang tersebar di berbagai wilayah, seperti Merangin, Sarolangun, Batanghari, Tajab Barat, Tebo, dan Bungo. Sedangkan populasi suku Anak Dalam secara keseluruhan mencapai hingga 5.000 jiwa" (Wawancara, Suryadi, Minggu, 3 Januari 2021, Populasi Suku Anak Dalam, Sarolangun). Data tersebut merupakan data spekulasi berdasarkan riset di lokasi. Hal ini dikarenakan suku Anak Dalam memiliki pola hidup yang seminomaden atau selalu berpindahpindah. Pola hidup ini membuat suku Anak Dalam sulit untuk terdata jumlahnya. Hal ini mengakibatkan populasi suku Anak Dalam tidak pernah diketahui secara pasti.

Tradisi dari suku Anak Dalam yang masih bertahan dan dilestarikan adalah tradisi melangun. Melangun merupakan tradisi melakukan perjalanan suku Anak Dalam dari kampung. Perjalanan ini dilakukan tanpa persiapan, karena semua barang harus ditinggalkan. Jalaludin Jenang mengatakan: "Rute atau tujuan dari 
melangun tidak ditentukan, artinya orang yang melangun melakukan perjalanan sejauh-jauhnya dari kampung halaman. Tujuan dari tradisi ini adalah menghormati roh dari anggota keluarga yang meninggal dan untuk menghilangkan kesedihan setelah kehilangan anggota keluarga (Wawancara, Jalaludin Jenang, Senin, 4 Januari 2021, Tradisi Melangun, Bukit Dua Belas).

Melangun telah menjadi bagian dari sistem adat suku Anak Dalam sejak zaman dahulu. Setiap anggota masyarakat dari suku Anak Dalam yang tidak melaksanakannya dianggap sebagai pelangar adat istiadat. Konsekuensi dari pelanggaran tersebut adalah menjalani berbagai hukuman, mulai dari denda hingga hukuman mati, tergantung tingkat kesalahannya. Bahkan, jika ada anggota keluarga yang melanggar, maka anggota keluarga yang lain juga harus menanggung hukumannya. Aturan adat tersebut menjelaskan bahwa tradisi melangun merupakan tradisi wajib bagi suku Anak Dalam.

\section{KAJIAN TEORI}

\section{Teater Kontemporer}

Penggarapan karya ini mengusung konsep teater kontemporer. Secara etimologi, kontemporer merujuk pada situasi saat ini. Teater kontemporer dapat didefinisikan sebagai teater yang mengusung konvensi yang mutakhir. Yudiaryani (2010: 2) mengatakan: "Teater kontemporer adalah upaya untuk membaca perkembangan kreativitas dengan membaca bentukbentuk pewarisan dan pelestarian seni teater daerah".

Pertunjukan teatrikal kontemporer hadir melalui dua bentuk, yaitu bentuk realisme modern dengan gaya seleksi dan stilisasi, serta bentuk revitalisasi realisme dengan gaya nonrealis dan postrealis atau postmodern (Yudiaryani, 2010: 13).

\section{Konvensi Panggung Proscenium}

Susantono (2016: 93) mengatakan: "Proscenium adalah panggung yang memiliki bingkai yang membentuk bukaan panggung yang terletak persis di depan tirai utama. Proscenium membatasi antara panggung dengan auditorium". Pemilihan panggung ini dimaksudkan agar vokal aktor dapat terdengar jelas karena dibantu dengan akustik gedung, sehingga aktor tidak membutuhkan bantuan alat pengeras suara. Proscenium juga memiliki sisi panggung (wing) yang dapat menjadi tempat aktor bersiap-siap memasuki panggung tanpa terlihat oleh penonton. Konsep panggung ini juga dapat membuat pertunjukan berjalan tanpa gangguan, karena ada jarak antara pertunjukan dan tontonan.

\section{Eksplorasi Seni Budaya}

Eksplorasi seni budaya adalah kegiatan mempelajari seni tradisi atau simbol etnik yang menjadi struktur di dalam budaya. Capaian dari hasil ini adalah mendapatkan rangsangan yang dapat memperkuat kreativitas (Irianto, 2020: 88).

Susanti (2017: 63) menjelaskan bahwa eksplorasi seni tradisi adalah pencarian kreatif di luar diri untuk mendapatkan rangsangan atas fenomena. Teori ini dimanfaatkan sebagai basis dalam mengembangkan seni tradisi dan mempelajari budaya dari suku Anak Dalam.

\section{METODE PENELITIAN}

\section{Riset}

Data-data riset didapatkankan dengan cara mendatangi pemukiman suku Anak Dalam di Bukit Dua Belas, Jambi. Riset awal telah dilakukan pada tanggal 4 Januari 2021. Sedangkan untuk riset lanjutan bersifat tentatif (sesuai kebutuhan). Data-data yang dibutuhkan dalam riset ini adalah mengetahui prilaku masyarakat, sistem sosial, sistem kepercayaan, seni yang berkembang dan prosesi dari tradisi melangun.

\section{Penyusunan Naskah}

Ide cerita dan alur dramatik disusun berdasarkan imajinasi subjektif. Sedangkan data-data di lapangan dimanfaatkan untuk kebutuhan pengayaan ide dan kebutuhan artistik. Penulisan naskah ini dilakukan berdasarkan diskusi dan izin dari para pemangku adat suku Anak Dalam. Spirit yang dibangun dalam proses penulisan naskah ini adalah menampilkan suku Anak Dalam yang selama ini tersembunyi di dalam hutan.

\section{Memilih Tim Kreatif}

Karya ini merupakan kolaborasi dari beberapa seniman dengan berbagai disiplin ilmu, seperti dramaturg, koreografer dan komposer. Dramaturg bertugas untuk membantu tafsir dan menawarkan kemungkinan eksekusi panggung. Sedangkan koreografer bertugas untuk menggarap tari dan mengolah gerak-gerak aktor. Terakhir adalah komposer yang bertugas untuk mempelajari musik-musik khas melayu Jambi untuk menyusun komposisi musik yang baru.

\section{Latihan Terpisah}

Proses latihan dilakukan terpisah agar pematangan setiap detail bagian menjadi lebih matang. Evaluasi dilakukan disetiap latihan agar progres karya berjalan sesuai rencana. Dramaturg bekerja sebagai pengatur casting, acting, dan blocking. Koreografer bekerja sebagai pemilih gerak dan memimpin pencarian bentuk 
tarian. Sedangkan komposer bertugas untuk menyusun dan melatih pemusik.

\section{Latihan Gabungan}

Setelah bagian aktor, tari dan musik telah matang, latihan gabungan dilaksanakan. Latihan gabungan ini awalnya diselenggarakan per-bagian. Fokus dari latihan ini adalah penggabungan antara musik, tari dan teater. Latihan dibagi menjadi 6 bagian, yaitu bagian opening, transisi adegan 1, transisi adegan 2, transisi adegan 3 , transisi adegan 4 , transisi adegan 5, transisi adegan 6 dan ending. Capaian dari proses ini adalah terciptanya ensemble, agar karya menjadi satu kesatuan yang utuh.

\section{HASIL DAN PEMBAHASAN}

\section{Hasil}

\section{1). Tema}

Tema mayor yang diusung dalam karya Meretas Adab yaitu konfrontasi antara kehendak manusia dan hukum adat. Konflik terbangun melalui gugatan individu atas tradisi yang mengekang kebebasannya. Tema mayor ini disampaikan melalui tokoh Melayau Tuah yang mengalami persoalan dilematis. Melayau dihadapkan oleh dua pilihan yang berat, yaitu patuh pada aturan adat atau memperjuangkan kesehatan ibunya.

Puncak konflik dari karya Meretas Adab adalah pilihan Melayau Tuah untuk menentang tradisinya. Rasa cintanya yang besar kepada ibunya membuat Melayau melawan aturan adatnya. Perlawan tersebut menjadi semakin ironis karena untuk menentang adat, Melayau dihadapkan oleh konflik dengan Temenggung yang merupakan pemimpin adat sekaligus calon suaminya. Namun, kekuatan tekad dari Melayau membawanya pada akhir yang tragis, karena Melayau harus menjalani hukuman adat yang berlaku.

Sedangkan tema minor dari karya Meretas Adab mengangkat isu tentang lingkungan. Persoalan yang menjadi fokus dalam tema minor ini adalah eksploitasi alam yang merugikan pihak suku Anak Dalam. Isu ini disampaikan melalui dialog tokoh Melayau Tuah yang meresahkan tentang kerusakan alam yang terjadi disekitarnya. Kerusakan alam dalam karya Meretas $A d a b$ hadir melalui dialog antar tokoh yang menjelaskan tentang hilangnya lahan, menurunnya kualitas air dan berkurangnya jumlah hewan buruan di hutan.

Kehadiran isu lingkungan ini memperkuat kehadiran dan konflik yang terbangun dari tema mayor, dimana suku Anak Dalam menjadikan orang di luar lingkungan masyarakatnya sebagai pelaku utama atas eksploitasi alam yang terjadi. Sehingga ketidakpercayaan suku Anak Dalam kepada orang luar menjadikan pertentangan antara Melayau Tuah dan masyarakat suku Anak Dalam menjadi semakin rumit. Melayau percaya bahwa tidak semua orang luar daerahnya adalah orang jahat, karena itulah Melayau ingin pergi dari kampung agar bisa mendapatkan obat untuk ibunya. Sedangkan masyarakat suku Anak Dalam telah begitu sentimen dan melarang anggota masyarakatnya untuk menjalin hubungan yang intens dengan orang luar.

\section{2). Alur}

Karya Meretas Adab menggunakan alur yang disusun oleh Aristoteles. Pemilihan konsep ini bertujuan agar dramatik cerita dapat terbaca dan hubungan sebab akibat tersusun secara logis. Aristoteles (dalam Dewojati, 2010: 164) membagi alur menjadi, yaitu eksposisi, komplikasi, klimaks dan konklusi. Eksposisi ini adalah pelukisan awal, komplikasi adalah perumitan peristiwa, klimaks adalah puncak dari masalah dan konklusi adalah penyelesaian.

\section{(1). Eksposisi}

Tiga poin penting dari eksposisi adalah penggambaran kondisi ibu Melayau Tuah yang sedang sakit. Kemudian penggambaran Temenggung sebagai pemuka adat sekaligus calon suami dari tokoh Melayau Tuah. Poin terakhir adalah keberpihakan Melayau Tuah kepada orang terang atau orang yang tinggal di luar perkampungan suku Anak Dalam.

\section{(2). Komplikasi}

Penggambaran komplikasi dalam karya Meretas Adab pada bagian ketiga, dimana teman-teman Melayau datang membawa daun obat untuk ibunya yang sakit. Namun, semua daun obat tersebut sudah Melayau berikan kepada ibunya, sayangnya kondisi kesehatan ibunya belum juga membaik. Akhirnya Melayau Tuah memutuskan untuk pergi menemui dokter di luar kampungnya. Meskipun hal tersebut merupakan salah satu pelanggaran adat, namun Melayau tetap kukuh demi kesehatan ibunya.

\section{(3). Klimaks}

Penggambaran klimaks dari karya Meretas Adab adalah pada bagian ke empat, dimana Melayau Tuah pergi ke luar kampung untuk menemui dokter. Berita tersebut tersebar ke seluruh kampung hingga ke Temenggung. Temenggung yang marah memerintahkan warga untuk menangkap Melayau. Setelah tertangkap, terjadi perdebatan antara Melayau Tuah dan Temenggung. 
Konflik dibangun melalui konfontasi antara Temenggung yang menganggap Melayau telah melanggar adat dan Melayau yang merasa tidak melakukan kesalahan apapun. Puncak dari konflik tersebut adalah Melayau menolak menjadi istri Temenggung dan tetap bersikeras untuk membawa ibunya menemui dokter. Merasa tidak dihargai sebagai pemuka adat, Temenggung akhirnya memerintahkan masyarakat untuk menangkap dan mengurung Melayau. Perintah itu juga yang telah menggagalkan Melayau untuk pergi ke luar kampung.

\section{(4). Konklusi}

Konklusi dari karya Meretas Adab menggambarkan dua masalah yang dialami oleh Melayau, yaitu kematian ibunya dan hukuman adat yang harus dijalaninya. Temenggung yang merupakan pemuka adat tidak ragu sedikitpun untuk menjatuhi hukuman adat kepada Melayau. Hukuman inilah yang menjadi akhir dari hidup Melayau Tuah. Akhir dari Konklusi adalah penggambaran tradisi melangun oleh suku Anak Dalam setelah kematian Melayau dan ibunya.

\section{3). Penokohan}

\section{(1). Melayau Tuah}

Tokoh Melayau Tuah adalah tokoh protagonis yang mengatur alur dramatik di dalam karya Meretas Adab. Kehadiran tokoh Melayau adalah representasi dari ide tentang perlawanan tradisi yang merupakan ide pokok dari karya Meretas Adab. Tokoh Melayau Tuah merupakan corong dari visi pengkarya tentang tatanan adat yang terlalu kaku dan konservatif.

Melayau Tuah sebagai tokoh utama disusun berdasarkan lima kriteria karakter utama menurut Ledwin (2008: 10). Dimana tokoh Melayau memiliki aksi yang mengangkat cerita, karena karya Meretas $A d a b$ menceritakan tentang dirinya. Melayau juga memiliki kamauan dan kemampuan untuk mencapai cita-citanya, meskipun mendapatkan rintangan, Melayau tetap teguh pendirian dan tidak menyerah. Tekad yang besar itu dimiliki Melayau karena rasa empatinya kepada ibunya. Berdasarkan penjabaran di atas, maka tokoh Melayau memenuhi 5 dari kriteria tokoh utama.

Berdasarkan tipe karakter, tokoh Melayau Tuah dapat digolongkan ke dalam Round Character. Dimana watak tokoh Melayau Tuah tidak stagnan sepanjang alur drama, melainkan bertumbuh dan mengalami peningkatan yang signifikan. Perkembangan karakter tokoh Melayau Tuah tergambar dari peningkatan intensitas emosi hingga mencapai klimaks.
Secara fisiologis, tokoh Melayau adalah wanita berusia 25 tahun yang memiliki paras yang cantik. Penegasan kecantikan dari tokoh Melayau digambarkan melalui terpilihnya Melayau sebagai calon istri Temenggung. Secara sosiologis, Melayau adalah wanita yang peduli dengan lingkungan. Penegasan kepedulian tokoh Melayau kepada lingkungan digambarkan melalui keresahannya atas kondisi hutan yang memprihatinkan. Selain itu, Melayau juga memiliki banyak teman di kampung. Lingkungan sosial yang ramah kepada tokoh Melayau digambarkan melalui tokoh Perempuan I dan Perempuan II yang membawakan obat setelah mendengar ibu Melayau sedang sakit.

Secara psikologis, tokoh Melayau adalah wanita yang cerdas dan memiliki pikiran yang terbuka. Kecerdasan tokoh Melayau tergambar dari pola pikirnya yang tidak kaku untuk memahami sebuah tradisi. Melayau juga tidak terperangkap pada paradigma warga kampung yang menganggap orang terang (orang dari luar kampung) adalah orang yang jahat. Namun, Melayau memiliki tekad yang kuat, sehingga membuatnya menjadi wanita yang keras dan mandiri. Jika Melayau yakin tentang sebuah kebenaran, maka ia memegang teguh setiap kepercayaan yang diyakininya. Sifat keras dan pantang menyerah inilah yang menjadikan tokoh Melayau berani melanggar hukum adat dan menentang pemuka adat.

\section{(2). Temenggung}

Temenggung adalah tokoh Antagonis di dalam karya Meretas Adab. Sebagai tokoh penentang, kehadiran Temenggung menjadi anti tesis dari setiap pemikiran dan kehendak tokoh Melayau. Meskipun tokoh Temenggung tidak hadir di setiap babak, namun persoalan menyangkut Temenggung selalu hadir di setiap babak.

Berdasarkan tipe karakter, tokoh Temenggung dapat digolongkan ke dalam flat character. Hal ini digambarkan melalui intensitas emosi dari tokoh Temenggung yang stagnan. Meskipun setiap dialog tokoh Temenggung diucapkan dengan intensitas emosi yang tinggi, namun intensitas emosi tersebut tetap dipertahankan secara datar dan tidak mengalami perubahan yang signifikan.

Secara fisiologis, tokoh Temenggung adalah lelaki berusia 35 tahun dengan tubuh yang tegap. Secara sosiologis, Temenggung tergolong ke dalam kelas sosial yang terpandang. Hal ini dikarenakan tokoh Temenggung merupakan seorang pemangku adat. Sebagai pemuka adat, Temenggung patuh kepada aturan adat yang berlaku. Temenggung akan selalu 
menegakkan aturan adat, meskipun berkaitan dengan orang-orang terdekatnya. Temenggung belum memiliki pasangan, tetapi ia telah memilih Melayau sebagai calon istrinya.

Secara psikologis, tokoh Temenggung adalah pribadi yang tegas dan patuh kepada aturan. Meskipun calon istrinya adalah pelanggar aturan, Temenggung tidak segan untuk menjatuhi hukuman secara tegas. Sebagai pemimpin, Temenggung memiliki kecenderungan ingin dihargai. Kepribadian ini tergambar dari cara Temenggung yang marah kepada Melayau karena Melayau tidak menghargainya. Ketersinggungan inilah yang menjadi salah satu faktor yang membuat Temenggung tidak ragu untuk menjatuhi hukuman kepada Melayau.

\section{(3). Dokter}

Tokoh Dokter adalah perwakilan orang terang (orang yang berasal dari luar kampung suku Anak Dalam). Tokoh Dokter dapat digolongkan sebagai tokoh Deutragonis. Jenis kedudukan ini tergambar dari keberpihakan tokoh dokter kepada tokoh utama. Meskipun demikian, tindakan tokoh Dokter untuk berpihak kepada tokoh Melayau adalah bagian dari tugas seorang dokter. Kewajaran ini dimaksudkan tanpa ada tendensi apapun, melainkan untuk membangun cerita secara logis dan realistis.

Penggambaran tokoh Dokter secara fisiologis, sosiologis dan psikologis tidak digambarkan secara spesifik. Hal ini dikarenakan tokoh Dokter hanya terlibat pada satu adegan saja. Selain itu, tokoh Dokter juga tidak terlibat di dalam adegan puncak dramatik cerita. Meskipun demikian, kehadiran tokoh Dokter menjadi sangat penting untuk menggambarkan bahwa orang terang atau orang dari luar suku Anak Dalam tidak selalu jahat.

\section{(4). Tokoh Pendukung}

Selain tokoh Melayau dan Temenggung, karya Meretas $A d a b$ juga didukung oleh beberapa tokoh pendukung yang tidak memiliki identifikasi yang jelas. Ketidakjelasan identifikasi tokoh pendukung ini dimaksudkan untuk menyimbolkan perwakilan masyarakat yang beragam. Selain itu, kehadiran tokoh pendukung hanya sebagai pendukung atau penentang setiap pemikiran dari tokoh utama. Setiap tokoh pendukung tidak diberi nama. Penamaan tokoh menggunakan nama Perempuan I, Perempuan II, Lelaki I, Lelaki II, Warga I dan Warga II.

Tokoh pendukung digarap secara multicast atau setiap aktor dapat memiliki peran yang ganda. Artinya, para aktor terkadang menjadi penari, kru panggung, masyarakat dan teman dari tokoh utama. Konsep multi peran inilah yang membuat karakter setiap tokoh pendukung tidak digambarkan secara detail. Dilihat dari tipe karakternya, setiap tokoh pendukung dapat digolongkan ke dalam flat character. Tokoh pendukung tidak memiliki karakter yang bertumbuh atau memiliki intensitas emosi yang dinamis, melainkan karakter setiap tokoh pendukung disesuaikan dengan kebutuhan dramatik di setiap adegan.

Berdasarkan tipe perwatakan, tokoh pendukung memiliki tipe yang serupa. Secara fisiologis tidak ada penggambaran yang spesifik. Tokoh pendukung digambarkan tidak seragam untuk mendapatkan impresi warga kampung. Secara sosiologis, tokoh pendukung dapat digolongkan pada kelas sosial menengah ke bawah, hal ini dikarenakan setiap tokoh pendukung adalah perwakilan masyarakat, sehingga tidak satupun dari tokoh pendukung yang merupakan bagian dari pemuka adat.

Secara psikologis, tokoh pendukung memiliki kecenderungan untuk mengambil tindakan tanpa berpikir panjang. Kondisi kejiwaan ini dihadirkan untuk mendukung alur untuk mencapai puncak dramatik. Tokoh pendukung hadir di setiap adegan untuk menentang atau menjatuhkan tokoh utama agar alur dramatik terbangun secara logis. Meskipun demikian, kehadiran tokoh pendukung menjadi salah satu unsur esensial untuk mendukung karya Meretas Adab.

\section{Pembahasan}

\section{1). Dialog}

Dialog dalam karya Meretas Adab adalah media utama untuk menyampaikan pesan cerita. Alur, latar dan tema disampaikan secara eksplisit melalui dialog antar tokoh. Dialog tokoh di dalam karya Meretas Adab menggunakan bahasa Indonesia dengan memanfaatkan idom khas suku Anak Dalam. Setiap aktor dituntut untuk patuh kepada dialog di dalam naskah agar dramatik pertunjukan dapat terjaga kestabilannya. Artinya, dialog spontan atau improvisasi diminimkan.

Selain dialog, soliloquy juga dimanfaatkan sebagai pola tutur. Soliloquy dihadirkan bukan untuk menjelaskan cerita sebagaimana narator, namun soliloquy dimanfaatkan untuk kebutuhan ekspresi personal tokoh. Soliloquy digunakan secara otonom atau terlepas dari setiap adegan. Artinya, soliloquy hadir dan membentuk adegan tersediri. Soliloquy hanya disampaikan oleh dua aktor, yaitu Melayau Tuah dan Temenggung. 
Selain itu, mendendangkan syair juga digunakan sebagai pola tutur. Syair yang digunakan merupakan syair dari suku Anak Dalam. Pola tutur ini digunakan sebagai pembuka adegan. Irama dendang yang dimanfaatkan adalah musik khas suku Anak Dalam dan berpadu dengan irama musik melayu. Tiga pola tutur tersebut digunakan untuk memberikan variasi agar komunikasi berjalan secara efektif dan variatif.

\section{2). Spektakel}

Spektakel dari karya Meretas Adab mengusung konsep sugestif, dimana latar waktu dan latar tempat tidak dihadirkan secara utuh. Melainkan hanya sugestisugesti untuk melahirkan impresi yang realistis di imajinasi penonton. Semangat yang digunakan adalah semangat menciptakan ilusi dari kenyataan, namun ilusi tersebut disampaikan melalui sugesti. Selain itu, beberapa adegan digarap secara simbolis untuk mengungkapkan ekspresi-ekspresi bawah sadar yang tidak mampu disampaikan secara realistis. Penyampaian adegan simbolis ini diwakili oleh tarian dan nyanyian.

\section{(1). Koreografi}

Unsur koreografi dimanfaatkan sebagai transisi adegan agar alur dramatik dan intensitas emosi setiap adegan tetap terhubung. Para penari memainkan multi peran, dimana penari memiliki tugas sebagai penari, aktor sekaligus kru panggung. Konsep multi peran ini digunakan agar antara tarian dan adegan menjadi satu kesatuan. Koreografi yang dihadirkan terbagi menjadi 5 bagian, yaitu tarian pembuka, tarian transisi bagian 3 , transisi bagian 4 , transisi bagian 5 dan tarian penutup.

Tari bagian 2 berangkat dari prilaku keseharian suku Anak Dalam. Beberapa prilaku yang diambil sebagai dasar gerak adalah aktivitas berburu dan aktivitas bercocok tanam. Selain berangkat dari aktivitas seharihari, media eksplorasi yang dimanfaatkan adalah benda-benda yang digunakan masyarakat suku Anak Dalam ketika beraktivitas, seperti tampah, bakul, dan tombak. Untuk tempo dan irama gerak disusun berdasarkan rangsangan dari musik. Tari bagian 3 menggambarkan keadaan suku Anak Dalam ketika berburu. Ekspresi yang ditonjolkan adalah keresahan karena berkurangnya hasil buruan. Dasar gerak yang dimanfaatkan adalah gerak berburu yang dikombinasikan dengan gerak tari melayu Jambi, yaitu gerak keluk paku.

Tari bagian 4 dimanfaatkan sebagai isian transisi adegan. Konsep koreografi dari tarian ini adalah tari yang berangkat dari kebiasaan fisikal masyarakat suku Anak Dalam, yaitu duduk jongkok dan jalan bungkuk.
Agar eksplorasi gerak lebih variatif, aktivitas tersebut dipadukan dengan teknik berputar dan gerak tari melayu Jambi.

Tari bagian 5 menghadirkan tarian yang mengangkat peristiwa kematian. Gerak yang dipilih adalah gerak yang berangkat dari ritual melangun dari suku Anak Dalam, agar nuansa magis lebih terasa. Ekplorasi gerak juga memanfaatkan teknik tari modern. Sikap penari cenderung menundukkan kepala agar kesan kesedihan lebih tergambar.

Bagian penutup menggambarkan ritual penghukuman secara adat. Konsep koreografi pada tarian ini memanfaatkan kain panjang sebagai properti. Pemanfaatan kain panjang ini dimaksudkan sebagai hukuman yang harus Melayau bayar, yaitu denda kain. Pilihan gerak yang dipilih adalah gerak merentakrentak, berteriak dan gerakan memukul diri sendiri. Pemilihan gerak tersebut untuk menyampaikan kesakitan tubuh dan ketidakterimaan tokoh Melayau saat dihukum secara adat.

\section{(2). Properti}

Properti yang digunakan dalam karya Meretas Adab adalah barang-barang yang biasa digunakan oleh masyarakat suku Anak Dalam saat beraktivitas seharihari. Pemanfaatkan properti ini digunakan dengan tujuan untuk menambah kesan realistis pada setiap peristiwa. Namun, properti tersebut tidak hanya digunakan sebagai properti aktor, tetapi juga dimanfaatkan sebagai media eksplorasi penari.

Pemanfaatan properti digunakan secara fleksibel sesuai kebutuhan adegan. Properti mainkan secara realistis untuk bisnis akting ketika adegan dan properti dimainkan secara eksploratif ketika transisi adegan. Eksplorasi ini bertujuan untuk mencari kemungkinan dari pemanfaatan properti yang lebih luas dan lebih kaya secara artistik.

Properti pertama adalah Properti pertama adalah ambung. Ambung adalah tempat penyimpanan yang biasa digunakan untuk peralatan atau bahan makanan. Terbuat dari anyaman bambu dan rotan Ambung biasa digunakan oleh suku Anak Dalam untuk mengumpulkan buah atau sayuran di hutan.

Properti ambung digunakan oleh para tokoh pendukung yang mewakili masyarakat. Properti ini menegaskan bahwa suku Anak Dalam menyambung hidup melalui perkebunan dan hutan. Properti ini digunakan pada bagian kedua untuk adegan perempuan membersihkan 
Gorga : Jurnal Seni Rupa

Volume 10 Nomor 02 Juli-Desember 2021

p-ISSN: 2301-5942 | e-ISSN: 2580-2380

jagung. Namun, properti ini juga digunakan sebagai properti tari ketika transisi adegan.

Properti kedua adalah alat masak. Properti ini digunakan oleh para tokoh perempuan untuk menggambarkan aktivitas keseharian dari perempuan suku Anak Dalam. Properti ini tidak hanya digunakan sebagai properti tangan aktor, tetapi juga properti yang mendukung set panggung. Properti alat masak tidak dieksplorasi untuk transisi adegan, tetapi lebih kepada pendukung latar tempat.

Properti ketiga adalah tombak. Properti ini digunakan sebagai properti tangan para aktor laki-laki. Penggunaan tombak sebagai properti bertujuan untuk menggambarkan para laki-laki dari Suku Anak Dalam yang memiliki kebiasaan berburu. Selain menjadi properti tangan aktor, properti tombak juga digunakan untuk melengkapi set panggung.

Selain itu, properti tombak juga dimanfaatkan untuk properti tari. Eksplorasi tombak adalah upaya untuk menggambarkan suasana berburu dari masyarakat suku Anak Dalam. Tidak semua penari yang mengeksplorasi properti tombak, karena tombak hanya dipegang oleh aktor laki-laki. Pemanfaatan tombak sebagai properti tari ini digunakan pada transisi dan pembuka adegan.

Properti keempat adalah parang. Properti ini digunakan oleh aktor laki-laki sebagai perlengkapan untuk berburu. Selain itu, parang juga digunakan oleh tokoh Temenggung sebagai aksesoris tambahan. Selain digunakan untuk kebutuhan bisnis akting, properti tangan juga dimanfaatkan sebagai aksesoris yang melengkapi kostum para tokoh lelaki.

Properti kelima adalah tampah. Tampah adalah wadah berbentuk bulat yang terbuat dari anyaman. Properti tampah digunakan sebagai wadah dari daun obat dan jagung serta bahan makanan yang akan dibersihkan. Properti ini digunakan pada bagian 2 dan bagian 3 . Digunakan oleh aktor perempuan, termasuk tokoh Melayau Tuah.

Properti keenam adalah kain panjang. Properti ini digunakan sebagai properti simbolis untuk mewakili hukuman dan denda adat yang dijatuhi kepada Melayau Tuah. Properti kain digunakan pada ritual penghukuman Melayau Tuah. Kain panjang digunakan sebagai media eksplorasi para penari untuk ritual penghukuman. Kehadiran properti kain panjang merupakan simbol dari denda adat suku Anak Dalam, yaitu denda kain panjang.
Properti ke tujuh adalah kalung dan gelang. Properti ini digunakan sebagai penanda kelas sosial di antara masyarakat suku Anak Dalam. Ukuran dan panjang kalung menjadi penanda utama, seperti kalung panjang dan besar adalah kalung untuk Temenggung. Sedangkan kalung yang kecil digunakan untuk rakyat biasa. Properti kalung ini dimanfaatkan sebagai penunjang bisnis akting para tokoh.

Selain sebagai properti, kalung dan gelang juga digunakan sebagai aksesoris. Aksesoris ini merupakan aksesoris wajib yang dikenakan oleh masyarakat suku Anak Dalam. Kehadiran kalung dan gelang juga menjadi aksesoris untuk menunjang keutuhan kostum. Sehingga, selain bernilai guna secara aplikatif, properti ini juga bernilai guna secara artistik.

Properti selanjutnya adalah tandu. Tandu dirancang dengan bahan dasar bambu yang dirangkai dan dieratkan menggunakan tali. Properti ini digunakan oleh tokoh Melayau untuk membawa ibunya ke rumah sakit. Selain itu, properti tandu juga dimanfaatkan sebagai penunjang set panggung setelah digunakan.

Properti tandu juga dimanfaatkan sebagai media eksplorasi penari. Koreografi tandu ini disusun untuk menggambarkan kesedihan tokoh Melayau ketika ibunya meninggal. Adegan ini digarap secara simbolis dan dimanfaatkan sebagai transisi adegan.

\section{(3). Set Panggung}

Konsep panggung yang digunakan dalam karya Meretas Adab adalah panggung prosenium. Namun, area permainan dibagi menjadi 3 bagian, yaitu panggung, apron kiri dan apron kanan. Pembagian area permainan ini menegaskan bahwa karya Meretas Adab tidak mengikuti hukum panggung prosenium yang baku, di mana area bermain hanya berada di dalam bingkai prosenium. Pembagian ruang ini dimaksudkan agar secara spektakel, pertunjukan Meretas Adab menjadi lebih multiperspektif. Selain itu, tiga ruang permainan ini digunakan untuk meminimalisirkan kesalahan dan kegaduhan ketika pergantian set panggung.

Ruang pertama memanfaatkan bagian panggung (di atas panggung prosenium). Bagian ini merupakan area permainan utama, dimana hampir semua adegan berlangusung di ruang pertama. Pemilihan area panggung sebagai wilayah utama dikarenakan bagian panggung memiliki ketersediaan ruang dan pencahayaan yang representatif. Sehingga berbagai kemungkinan artistik dapat dimanfaatkan. Ruang kedua adalah apron bagian kanan. Wilayah ini 
digunakan untuk adegan Melayau Tuah bertemu dengan dokter. Pemanfaatan ruang ini dimaksudkan untuk membedakan antara wilayah perkampungan suku Anak Dalam dan wilayah orang terang (wilayah di luar perkampungan). Pemilihan ruang kedua ini juga memudahkan perpindahan set panggung secara teknis. Dimana set ruang kerja dokter tidak perlu mengganggu set perkampungan yang sudah ada, sehingga waktu yang dibutuhkan untuk perpindahan adegan menjadi lebih ringkas.

Ruang ke tiga adalah apron bagian kiri. Wilayah ini digunakan untuk tempat pemusik. Karya Meretas Adab menjadikan pemusik sebagai bagian dari pertunjukan. Di mana beberapa repertoar dimainkan sebagai transisi adegan. Pemilihan apron bagian kiri dimaksudkan agar ketika cahaya fokus kepada pemusik, kru panggung bisa mengganti set di bagian panggung yang lain.

\section{(4). Tata Cahaya}

Penataan cahaya pada karya Meretas Adab terbagi menjadi 2 pencahayaan, yaitu pencahayaan suasana dan pencahayaan realistis. Dua konsep pencahayaan ini digunakan untuk membedakan antara adegan yang digarap secara simbolis dan adegan yang digarap secara realistis. Pencahayaan realistis menggunakan cahaya general. Pemilihan warna ini digunakan untuk memberikan kesan latar waktu, yaitu siang hari. Selain itu, cahaya general juga dapat menampilkan ekspresi aktor secara eksplisit. Sedangkan untuk konsep pencahayaan suasana memanfaatkan berbagai warna, yaitu merah, hijau, kuning, biru, oranye dan ungu.

Pemanfaatan berbagai warna ini untuk menampilkan impresi simbolis dari adegan dan menghidupkan suasana. Warna merah dimanfaatkan untuk adegan konflik, yaitu adegan ketika Melayau Tuah dijatuhi hukum adat. Sedangkan warna biru digunakan untuk mengekpresikan kesedihan dari tokoh Melayau Tuah. Untuk transisi adegan yang diisi oleh tarian-tarian simbolis, warna yang digunakan adalah perpaduan antara warna merah, hijau, kuning, biru, oranye dan ungu.

Lampuyang digunakan berjumlah 63 titik. 6 lampu follow zoom spot, 21 lampu zoom spot, dan 36 fresnel. 2 follow zoom spot digunakan untuk bagian apron kiri, 2 follow zoom spot digunakan untuk bagian apron kanan, 2 follow zoom spot untuk fokus aktor dan 21 zoom spot serta 36 fresnel untuk menyinari area panggung utama.

\section{(5). Tata Rias dan Busana}

Busana dirancang berdasarkan pakaian sehari-hari yang digunakan suku Anak Dalam, yaitu kain yang dijadikan sarung dan kemben. Konsep pakaian tersebut dikreasikan untuk kebutuhan pertunjukan, dimana beberapa bagian dirancang agar tidak mudah lepas ketika aktor atau penari bergerak. Dari modelnya pun dikembangkan, beberapa bagian yang terlalu terbuka dikreasikan agar dapat disesuaikan dengan etika kesopanan dalam berpakaian. Bahan kain yang digunakan sebagai dasar adalah hyget, karena tidak tembus pandang dan lembut. Agar kesan pakaian suku Anak Dalam tetap kuat, warna yang dipilih adalah warna coklat, dimana mayoritas suku Anak Dalam cenderung menggunakan kain berwarna coklat.

Kostum tokoh dirancang dengan potongan blus dengan tambahan aksen kain batik yang dibuat bergelombang pada bagian dada. Penambahan aksen ini digunakan untuk memberikan kesan kain kemben yang dililitkan di tubuh. Untuk bawaannya dirancang mengadobsi konsep hyget untuk menambah kesan kain kemben. Agar para aktor mudah bergerak, bawahannnya didesain dengan konsep celana crop. Celana ini didesain hanya sepanjang betis dengan bagian bawahnya semakin melebar. Desain celana ini memudahkan aktor untuk bergerak dan kecelakaan busana dapat diminimalisir.

Selain untuk riasnya, warna-warna yang dipiliih adalah warna yang cenderung gelap, seperti cokelat muda dan coklat tua. Pemilihan warna ini disesuaikan dengan warna kulit dari masyarakat suku Anak Dalam yang cenderung sawo matang. Desain rias disusun senatural mungkin agar kesan wajah keseharian di perkampungan dapat dipertahankan. Namun, agar ekspresi aktor menjadi lebih hidup, beberapa bagian tetap diberi penegasan, seperti mata, alis dan bibir.

Untuk mewujudkan desain rias di atas, maka untuk powdernya, warna bedak yang dipilih adalah ivory. Warna blush on adalah coral dan warna shading adalah brown. Untuk bagian matanya, eyelidnya menggunakan warna soft brown, eyelinernya menggunakan warna black, eylashesnya menggunakan warna black dan eyebrownya menggunakan warna grey brown. Untuk bagian bibirnya menggunakan lipstick berwarna coral brown dan mude brown.

\section{KESIMPULAN DAN SARAN}

\section{Kesimpulan}

Karya Meretas Adab merupakan sebuah proses penciptaan teater yang dilandasi oleh riset terhadap tradisi melangun suku anak dalam. Melangun adalah 
tradisi melakukan perjalanan meninggalkan kampung. Perjalanan ini dilakukan untuk menghilangkan kesedihan dan menghormati roh anggota keluarga yang telah meninggal. Melangun merupakan sebuah ritual yang wajib, sehingga bagi yang melanggar akan dijatuhi hukuman adat.

Berdasarkan riset atas tradisi melangun, pengkarya menyusun naskah berjudul Meretas Adab. Karya Meretas Adab mengusung tema tentang konfrontasi antara kehendak manusia dan tatanan adat yang berlaku. Meretas Adab mengisahkan tentang Melayau Tuah yang terpaksa menentang tradisi sukunya demi mendapatkan kesehatan ibunya. Pilihan tersebut akhirnya membawa tokoh Melayau Tuah menuju akhir yang tragis.

Bentuk teater yang menjadi konsep dasar penciptaan adalah bentuk teater kontemporer. Pemilihan bentuk teater ini dimaksdukan agar capaian artistik dapat lebih luas. Selain itu, berbagai macam dukungan teknologi juga dapat dimanfaatkan. Meretas Adab digarap secara kontemporer dengan memanfaatkan aktivitas keseharian masyarakat suku anak dalam sebagai material artistik, mulai dari berburu hingga bercocok tanam.

\section{Saran}

Karya Meretas Adab diproduksi di tengah pandemi Covid-19, sehingga banyak keterbatasan yang akhirnya menghambat proses kreatif. Kelemahan tersebut tentunya membuat penciptaan karya Meretas Adab memiliki banyak kekurangan, dari segi kematangan konsep hingga penggarapan. Pengkarya menyadari bahwa karya Meretas Adab memiliki capaian yang belum maksimal. Sehingga, pengkarya sangat membutuhkan kritik dan saran untuk mendukung dan melengkapi karya Meretas Adab.

Namun, sebagai karya teater yang mengangkat tentang suku Anak Dalam, karya Meretas Adab kiranya telah menunaikan tugasnya. Semoga karya ini secara konsep dan pertunjukan dapat memberikan informasi dan pengetahuan baru tentang suku Anak Dalam. Pengkarya berharap laporan karya Meretas Adab ini dapat dijadikan sebagai pemantik untuk karya seni selanjutnya yang mengangkat tentang suku Anak Dalam.

\section{DAFTAR RUJUKAN}

Ibrahim, M., Gurniwan, K. \& Djakarta, M. (2013).

Kehidupan Suku Anak Dalam di Kecamatan Air Hitam Kabupaten Sarolangun. Antologi Pendidikan Geografi, 1(3), 1-15. http://antologi.upi.edu/file/.

Irianto, Ikhsan, S. (2020). Recombination of Minangkabau Traditional Arts in Alam
Takambang Jadi Batu. Jurnal Ekspresi Seni, 22(1), 85-99.

Jalaludin. (2021). “Jenang”. Hasil Wawancara Pribadi: 5 Januari 2021, Sorolangun.

Ledwin, David, Joe and Robin Stockadale. (2008), The Architecture Of Drama Plot Character Theme Genre And Style. Plymouth: The Scarecrow Press, Inc.

Mailinar, N. (2013). Kehidupan Keagamaan Suku Anak Dalam di Dusun Senami Lii Desa Jebak Kabupaten Batanghari Jambi. Jurnal Kontektualita, 28(2), 247-271.

Suryadi, Tumanggung Rimbo. (2021). "Pemandu Wisata Sarolangun". Hasil Wawancara Pribadi: 4 Januari 2021, Kecamatan Sorolangun.

Susanti, Susi. \& Sherli Novalinda, R. (2019). Penciptaan Tari Breath In Dari Aktivitas Pencari Pensi di Danau Singkarak. Ekspresi Seni, 21(2), 139-149.

Susantono, Nurul P. (2016). Produksi Drama Musikal - Dari Ide ke Panggung. Jakarta: Gramedia.

Temenggung, Baladan. (2021). "Berburu". Hasil Wawancara Pribadi: 5 Januari 2021, Bukit Dua Belas Sarolangun.

Yudiaryani. (2010). Inspirasi Teoretis Bagi Praktik Pembentukan Teater Kontemporer Di Indonesia. Yogyakarta: UPT Perpustakaan ISI Yogyakarta. 